DOI: 10.1515/LPTS-2015-0035

\title{
MATHEMATICAL MODELING OF DUAL LAYER SHELL TYPE RECUPERATION SYSTEM FOR BIOGAS DEHUMIDIFICATION
}

\author{
S. Gendelis, A. Timuhins, A. Laizans, L. Bandeniece \\ Laboratory for Mathematical Modelling of Technological and \\ Environmental Processes, University of Latvia, \\ 8 Zellu Str., Riga LV-1002, LATVIA
}

\begin{abstract}
The main aim of the current paper is to create a mathematical model for dual layer shell type recuperation system, which allows reducing the heat losses from the biomass digester and water amount in the biogas without any additional mechanical or chemical components. The idea of this system is to reduce the temperature of the outflowing gas by creating two-layered counter-flow heat exchanger around the walls of biogas digester, thus increasing a thermal resistance and the gas temperature, resulting in a condensation on a colder surface. Complex mathematical model, including surface condensation, is developed for this type of biogas dehumidifier and the parameter study is carried out for a wide range of parameters. The model is reduced to $1 \mathrm{D}$ case to make numerical calculations faster. It is shown that latent heat of condensation is very important for the total heat balance and the condensation rate is highly dependent on insulation between layers and outside temperature. Modelling results allow finding optimal geometrical parameters for the known gas flow and predicting the condensation rate for different system setups and seasons.
\end{abstract}

Keywords: biogas, counter-flow heat exchanger, dehumidification, mathematical modelling.

\section{INTRODUCTION}

Biogas at the outlet usually has a high water vapour content, and condensation can cause corrosion. Dehumidification process between the biomass tank and combined heat and power (CHP) engine optimises the combustion process, resulting in an increase of engine efficiency and lower gas consumption, as well as prevents corrosion of pipework and system components [1]. Commonly used biogas drying processes include adsorption with the aid of silica gel and active charcoal, glycol wash as adsorptive processes and condensation drying with cold water heat exchanger or refrigerating machine [2]. Each of the mentioned methods needs an additional material or energy supply.

A completely different approach is analysed in this paper, it is based on heat exchange between two layers of the same gas, which are coupled in a counter-flow way (Fig. 1). Comparing with the other dehumidification processes, it does not re- 
quire any additional energy supply and improves the thermal resistance of a storage tank, thus, decreasing heat losses.

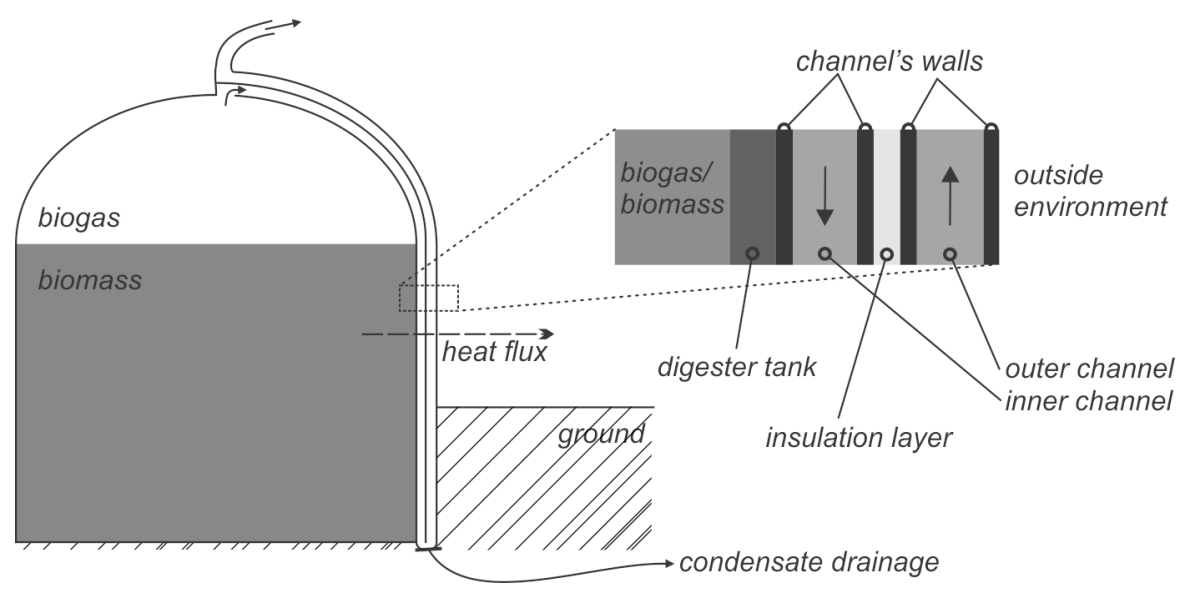

Fig. 1. Schematic illustration of a two-layered recuperation system for biogas cooling.

The main objective of this study is to find the optimal solution for the described recuperation and dehumidification system ensuring energy savings compared to the existing dehumidification methods. To achieve this goal, complex mathematical model has been developed and large parameter studies have been carried out to explore the influence of many environmental, geometrical and gas flow regime parameters on mass and heat transfer process. As a result, the dependence of heat losses and dehumidification intensity has been found. It helps improve the energy efficiency and gas drying effect.

\section{MODEL FORMULATION}

Thermal transmittance of the gas layer in a channel depends on gas flow regime $U_{g}=N u \cdot \lambda_{g} /(2 L)$, where $\lambda_{g}$ is gas thermal conductivity $\left(\mathrm{W} \mathrm{m}^{-1} \mathrm{~K}^{-1}\right)$ and $L$ is channel width (m); in our case the velocity is relatively small implying that the flow is laminar (calculated Reynolds number $R e<1500$ ), and the heat transfer at a channel surface within a fluid is characterised by a Nusselt number $N u$ [3], which is the ratio of convective to conductive heat transfer. The calculated Nusselt number value is $N u=3.66$, which shows that convective heat transfer is prevailing. It is assumed that the condensed water amount is removed from the system (condensed water drained by the walls).

Due to one channel temperature dependence on the other channel temperature, the described problem becomes non-linear and can be solved using gradual approximations. Iteration process for one case runs less than a minute thanks to simple and fast 1D model formulation; it takes much time in case when insulation between layers is thin, implying that temperatures become significantly interrelated.

A detailed mathematical model, iterative solving scheme and result visualisation are made using the Python programming language [4]. Discretization step for the calculation is set to $5 \mathrm{~cm}$. 
A principal sketch of the developed mathematical model and parameters used is shown in Fig. 2. Internal boundary splits the tank wall into two similar parts. Heat transfer process in each part describes the following equations:

- Thermal energy balance equation in a channel - temperatures changes are determined by heat losses through the channel walls and latent heat of condensation/vaporisation:

$$
\begin{aligned}
& \frac{\partial}{\partial x} v L\left(c_{g} \rho_{g}+c_{v} \rho_{v}\right) T=U_{1}\left(T_{l_{\text {in }}}-T_{1}\right)+U_{2}\left(T_{2}-T_{l_{\text {out }}}\right)+ \\
& \quad+2 L_{w} \frac{D}{L}\left(p-p_{1}^{*}\right)-2 L_{w} \frac{D}{L}\left(p_{2}^{*}-p\right)
\end{aligned}
$$

- Conservation law for the gas mixture without water vapour:

$$
\frac{\partial}{\partial x} v b L \rho_{g}=0 \text {. }
$$

- Conservation law for the water vapour, changes are possible due to condensation/vaporisation:

$$
\frac{\partial}{\partial x} v b L \rho_{v}=b_{w}\left(2 \frac{D}{L}\left(p-p_{1}^{*}\right)-2 \frac{D}{L}\left(p_{2}^{*}-p\right)\right) .
$$

- Heat flux densities through the channel walls $l=0$ and $l=L$ :

$$
\begin{aligned}
& U_{1}\left(T_{l_{\text {in }}}-T_{1}\right)+2 L_{w} \frac{D}{L}\left(p-p_{1}^{*}\right)=-U_{g}\left(T-T_{1}\right), \\
& -2 L_{w} \frac{D}{L}\left(p_{2}^{*}-p\right)-U_{g}\left(T_{2}-T\right)=U_{2}\left(T_{2}-T_{l_{\text {out }}}\right) .
\end{aligned}
$$

Variables for formulas (1-4) are $v, \rho_{g}, \rho_{v}, T_{1}, T_{2}, T$. Pressure and density are linked with the equation of state for an ideal gas:

$$
p=\rho \frac{R}{\mu} T .
$$

The saturation vapour pressure is dependent on the temperature of a gas.

The following designations are used for the above-mentioned formulas (see also Fig. 2): $v$ - velocity $\left(\mathrm{m} \mathrm{s}^{-1}\right), b$ - channel depth $(\mathrm{m}), c$ - heat capacity $\left(\mathrm{J} \mathrm{kg}^{-1}\right)$, $\rho$ - density $\left(\mathrm{kg} \mathrm{m}^{-3}\right), U$ - thermal transmittance $\left(\mathrm{W} \mathrm{m}^{-2} \mathrm{~K}^{-1}\right), L_{\mathrm{w}}$ - latent heat $\left(\mathrm{J} \mathrm{kg}^{-1}\right)$, $D=2 \cdot 10^{-7} \cdot T^{0.81} / P_{a}$ - water vapour diffusion coefficient $\left(\mathrm{kg} \mathrm{m}^{-1} \mathrm{~s}^{-1} \mathrm{~Pa}^{-1}\right), P_{a}-$ ambient atmospheric pressure $\left(10^{5} \mathrm{~Pa}\right), T$ - temperature $(\mathrm{K}), p^{*}$ - saturated water vapour pressure $(\mathrm{Pa}), p$ - water vapour pressure $(\mathrm{Pa}), l-$ axis perpendicular to the gas flow, $R$ - universal gas constant $\left(\mathrm{J} \mathrm{K}^{-1} \mathrm{~mol}^{-1}\right), \mu-$ molecular weight $\left(\mathrm{kg} \mathrm{mol}^{-1}\right)$. The used subscripts: $g$-gas, $v$ - vapour, $l_{\text {in }}$ - inner/internal surface, $l_{\text {out }}$ - internal surface/ outer. Wall overall heat transfer coefficient $U=1 /\left(R_{b}+R_{w}\right)$ depends on boundary layer (gas or liquid) thermal resistance $R_{b}$ and total wall material thermal resistance $R_{w}=\sum_{m} \lambda_{m} l_{m}$, where $l_{m}$ is $m$-th material layer thickness. 
Gas composition used for modelling contains methane $\mathrm{CH}_{4}$, carbon dioxide $\mathrm{CO}_{2}$, water vapour $\mathrm{H}_{2} 0$, oxygen $\mathrm{O}_{2}$ and nitrogen $\mathrm{N}_{2}$ [5]. Weighted average values for density $\rho=1606 \mathrm{~kg} \mathrm{~m}^{-3}$ and heat capacity $c_{g}=1787 \mathrm{~J} \mathrm{~kg}^{-1} \mathrm{~K}^{-1}$ are used in calculations. It is assumed that the gas mixture with relative humidity of $100 \%$ comes from a round container (see Fig. 1) with radius of $6 \mathrm{~m}$, height of $5 \mathrm{~m}$ and depth of segment under the ground level of $2 \mathrm{~m}$. Initial temperature of inflowing gas mixture from the storage tank $T_{\text {in }}$ is set to constant $38^{\circ} \mathrm{C}$. Radiation heat transfer is ignored because of relatively low temperature in the channel and the necessity to speed up the numerical calculations. Boundary conditions are defined by a temperature outside a thermal boundary layer, which is included in calculation by thermal resistances $R_{\mathrm{SE}}, R_{\mathrm{SI}}$ (see Table 1). Internal boundary condition is temperature and heat flux continuity requirement between channels.

The outside air and ground temperature (according to winter and summer conditions in Latvia), input gas flow, as well as insulation between counter-flow channel segments were varied to evaluate the influence on temperature distribution and condensation rate. Main parameters used in the calculations are summarised in Table 1.
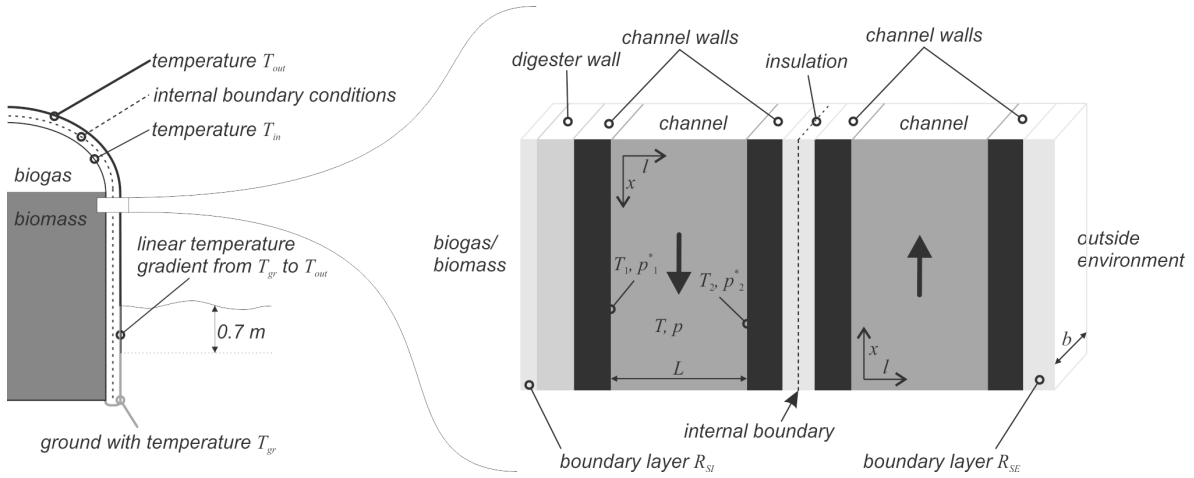

Fig. 2. A principal sketch of the developed mathematical model for each channel. Inner and outer materials differ for each channel (digester tank wall or a half of the insulation layer).

Table 1

Main Constants and Variable Parameters for Model Calculation

\begin{tabular}{|l|l|l|}
\hline Parameter (Figs. 1, 2) & Value & Unit \\
\hline Outside air temperature $T_{\text {out }}$ & $0 \ldots 30$ & ${ }^{\circ} \mathrm{C}$ \\
\hline Ground temperature $T_{g r}$ & $5 \ldots 7$ & ${ }^{\circ} \mathrm{C}$ \\
\hline Gas flow & $75 \ldots 200$ & $\mathrm{~m}^{3} \mathrm{~h}^{-1}$ \\
\hline Channel width & 1 & $\mathrm{~cm}$ \\
\hline Thickness of the insulation layer between channels & $0 \ldots 10$ & $\mathrm{~cm}$ \\
\hline Thickness of the channel wall & 0.5 & $\mathrm{~cm}$ \\
\hline Thickness of the digester wall & 0.5 & $\mathrm{~m}$ \\
\hline Exterior thermal resistance $R_{\mathrm{SE}}$ (to outside air) & 0.04 & $\mathrm{~m}^{2} \mathrm{~K} \mathrm{~W}^{-1}$ \\
\hline Interior thermal resistance $R_{\mathrm{SI}}$ (to the biogas) & 0.13 & $\mathrm{~m}^{2} \mathrm{~K} \mathrm{~W}^{-1}$ \\
\hline Interior thermal resistance $R_{\mathrm{SI}}$ (to the biomass) & 0.0001 & $\mathrm{~m}^{2} \mathrm{~K} \mathrm{~W}^{-1}$ \\
\hline Ground thermal conductivity & 2 & $\mathrm{~W} \mathrm{~m}^{-1} \mathrm{~K}^{-1}$ \\
\hline Thermal conductivity of the digester tank & 1 & $\mathrm{~W} \mathrm{~m}^{-1} \mathrm{~K}^{-1}$ \\
\hline Thermal conductivity of the channel wall & 0.19 & $\mathrm{~W} \mathrm{~m}^{-1} \mathrm{~K}^{-1}$ \\
\hline Thermal conductivity of the insulation layer & 0.033 & $\mathrm{~W} \mathrm{~m}^{-1} \mathrm{~K}^{-1}$ \\
\hline
\end{tabular}




\section{RESULTS AND DISCUSSION}

\subsection{Integral Values: Total Condensation Rate, Latent Heat, Heat Losses}

It is possible to simply evaluate the maximum possible amount of condensate generated for the gas, by knowing a saturated water vapour density at different temperatures [6]. This condensation rate $\left(\mathrm{kg} \mathrm{h}^{-1}\right)$ for different gas flows with relative humidity of $100 \%$, which cools down from $38^{\circ} \mathrm{C}$ to lower temperatures at the system outlet, is visualised in Fig. 3. It is seen that a condensation rate is increasing linearly with the flow rate of gas mixture including water vapour, but non-linear effects are seen for the decrease of outlet temperature (increasing the temperature difference). For the smallest temperature difference $\left(5^{\circ} \mathrm{C}\right)$ and the slowest flow $\left(75 \mathrm{~m}^{3} \mathrm{~h}^{-1}\right)$, the maximum condensation rate is $1.2 \mathrm{~kg} \mathrm{~h}^{-1}$, but for the largest temperature difference and flow values it increases to $8.3 \mathrm{~kg} \mathrm{~h}^{-1}$. This evaluation is important to estimate the real portion of the maximum possible condensation amount for a specific system. Further calculations for different geometrical cases and flows (see below) show that approximately $50 \%$ of the maximum possible water amount is condensed.

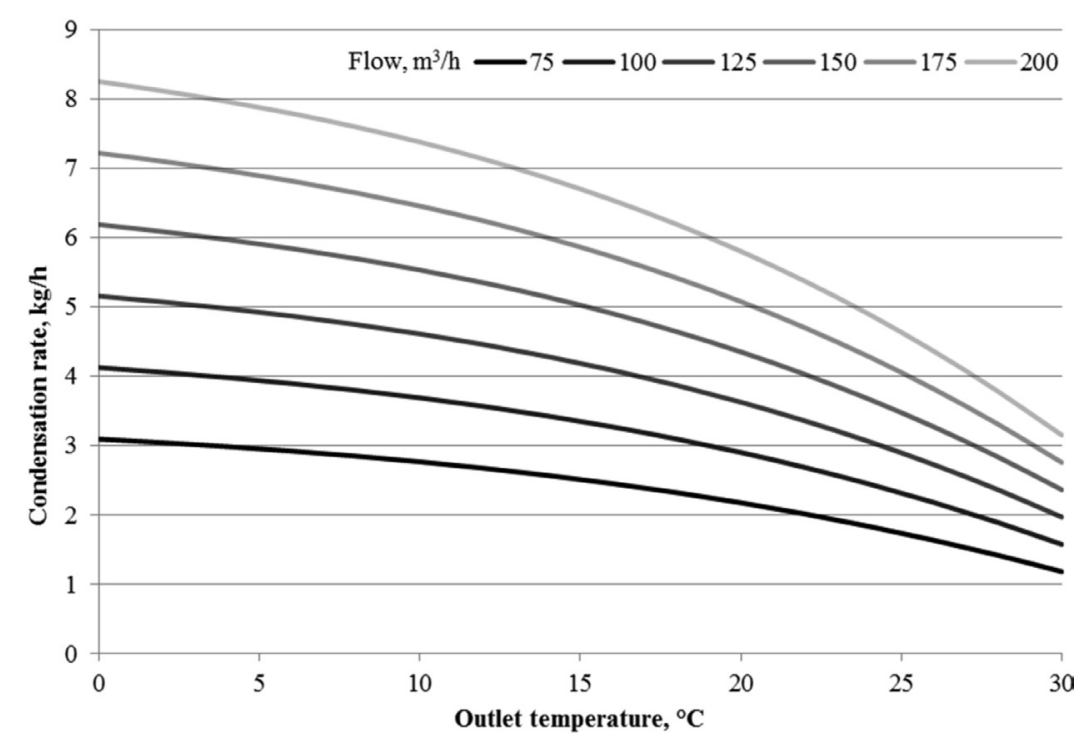

Fig. 3. The maximum possible condensation rate depending on the outlet temperature and gas flow.

If the insulation layer is placed between conjugated counter-flow channels (see Fig. 2), it reduces the interaction between gas temperature in the channels and decreases heat losses from the digester tank. On the other hand, it also influences the gas temperature in the channels, implying changes of the condensation rate on cold surfaces. Thereby, the modelling of different insulation layers helps estimate both the heat loss and gas dehumidification processes.

Two cases were modelled using the developed mathematical model - without any additional insulation layer between counter-flow channel walls and with $10 \mathrm{~cm}$ of insulation material with $\lambda=0.033 \mathrm{~W} \mathrm{~m}^{-1} \mathrm{~K}^{-1}$, which increases the overall thermal resistance of the wall by $R=3 \mathrm{~m}^{2} \mathrm{~K} \mathrm{~W}^{-1}$. Results of the change in a condensation 
rate are shown in Fig. 4. As it is seen, the influence of the thermal insulation layer between channels on the total condensation rate is relatively small, e.g. for the maximum gas flow and winter outside temperature conditions the difference is only $2 \%$. This is explained by the fact that outer wall of the outer channel is not insulated and the heat flow to the outside is limited by the outer channel; thus, condensation is basically dependent on outside temperature and gas flow rate. The presence of thermal insulation between channels only redistributes the amount of condensable water between inner and outer channels.

The insulation of outer channel outer wall impacts the temperature in this channel, thus significantly reducing the total condensation, implying that necessary drying will not happen in the system. Therefore, such configuration has not been modelled during the simulations.

Comparing the condensation rate in the modelled system with a maximum possible one (Fig. 3), it can be concluded that for the flow of $200 \mathrm{~m}^{3} / \mathrm{h}$ actual condensation rate is $49 \%$, but for flow of $75 \mathrm{~m}^{3} / \mathrm{h}$ it is $81 \%$. Therefore, it can be concluded that the condensation rate for real geometry systems cannot be precisely estimated using a simplified method for maximum condensate calculation.

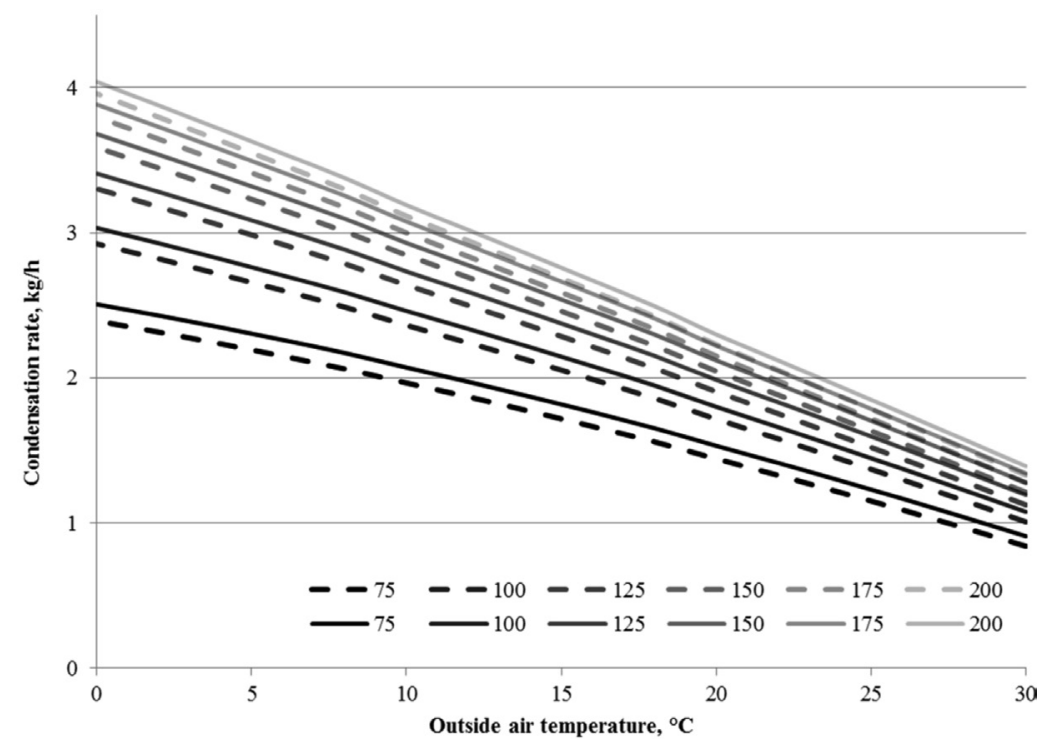

Fig. 4. Condensation rate in the system without insulation between the channels (solid lines) and with $10 \mathrm{~cm}$ thermal insulation (dashed lines).

The calculated gas temperature at system outlet for the cases described above with different insulation layers is shown in Fig. 5. As mentioned, an increase of thermal insulation between channels reduces the heat losses and decreases the condensation intensity in the inner channel; the gas flows into the outer channel with the highest temperature, and a condensation rate in it is higher than in case without insulation. As a result, an insulation layer practically does not affect the temperature at the outlet for intensive flows of $200 \mathrm{~m}^{3} \mathrm{~h}^{-1}$ (less than $1 \%$ for the wintertime), but for less intensive flow of $75 \mathrm{~m}^{3} \mathrm{~h}^{-1}$ the difference is about $10 \%$. Good thermal insulation between channels reduces conductive heat flux from inner to outer channel; 
therefore, temperature in the outer channel is more dependent on the environmental temperature outside. This effect is especially pronounced for low intensity flows.

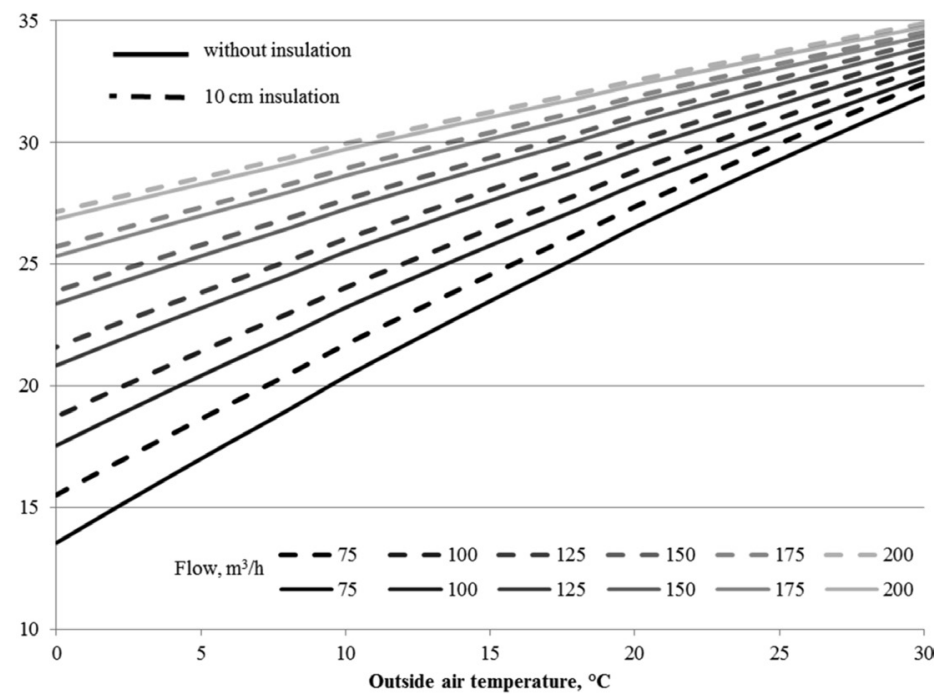

Fig. 5. Gas temperature at the system outlet without insulation between the channels (solid lines) and with $10 \mathrm{~cm}$ thermal insulation (dashed lines).

Latent heat released in the condensation process for different flows and outside air temperatures is shown in Fig. 6. It is proportional to the condensation rate (Fig. 4); the maximum power of $2.5 \mathrm{~kW}$ is calculated for $200 \mathrm{~m}^{3} \mathrm{~h}^{-1}$ flow in the winter period (outside air temperature $0^{\circ} \mathrm{C}$ ), it decreases to $1 \mathrm{~kW}$ in the summer. For the slowest flow of $75 \mathrm{~m}^{3} \mathrm{~h}^{-1}$ the maximum power is only $1.5 \mathrm{~kW}$ in the wintertime. As for condensation intensity, an insulation layer between channels has no significant influence also on total latent heat.

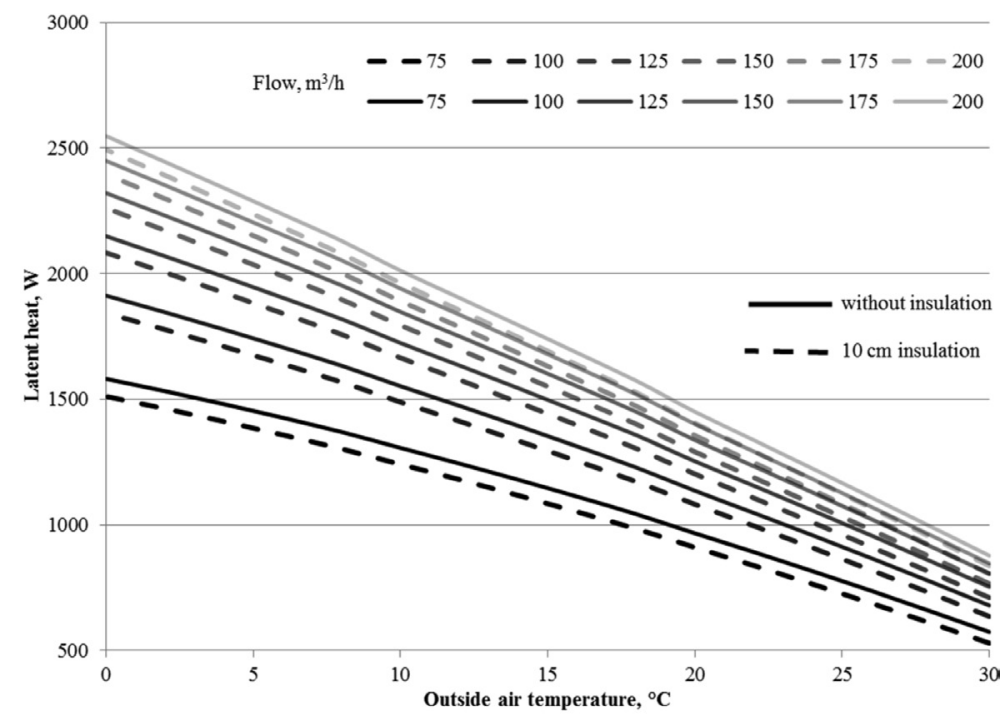

Fig. 6. Latent heat released in the system without insulation between the channels (solid lines) and with $10 \mathrm{~cm}$ thermal insulation (dashed lines). 
The developed recuperation system with two channels around the digester also reduces the heat losses from it thanks to additional thermal resistance. Figure 7 shows the total losses from the digester (including roof, wall and underground part of it, see Fig. 1) depending on variable parameters. As expected, the increase of relatively hot gas flow intensity reduces heat losses through the digester boundary structures. For example, in case of air temperature of $0{ }^{\circ} \mathrm{C}$ and without any insulation used between channels, an increase of gas flow from 75 to $200 \mathrm{~m}^{3} \mathrm{~h}^{-1}$ helps reduce heat losses six-fold - from 300 to $50 \mathrm{~W}$. If there is $10 \mathrm{~cm}$ insulation between layers, the same increase of flow reduces the losses six-fold - from 186 to $30 \mathrm{~W}$.

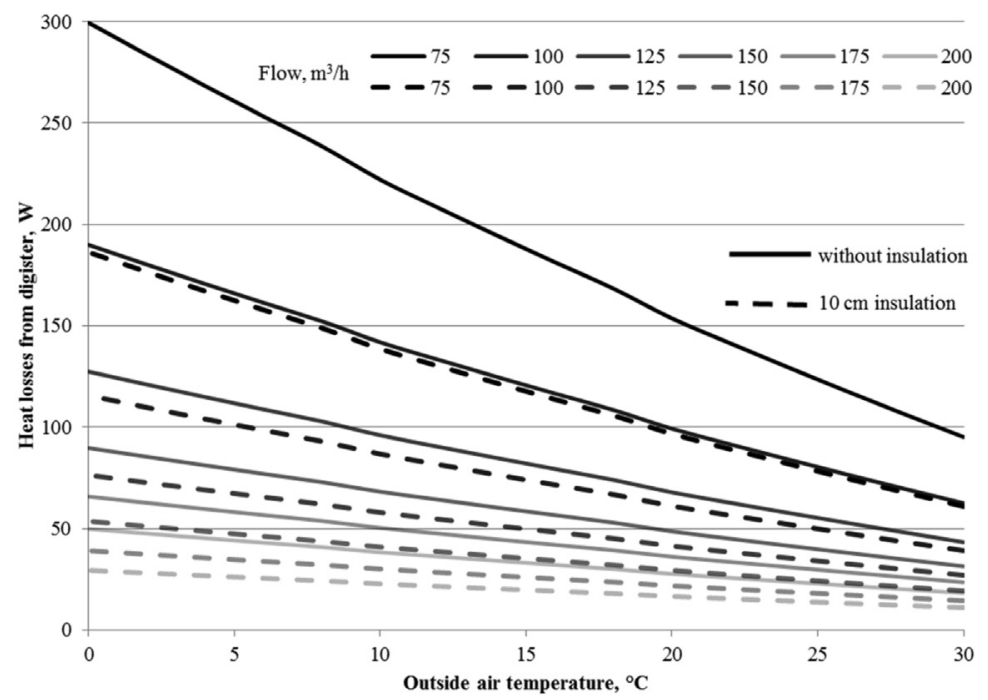

Fig. 7. Heat losses from the whole biogas digester without insulation between the channels (solid lines) and with $10 \mathrm{~cm}$ thermal insulation (dashed lines).

It has previously been found that thermal insulation has a low impact on the total condensation rate, but from the viewpoint of heat loss the double layer system with the insulation layer has an advantage, despite a two-fold reduction in heat losses at a fixed flow. It should be noted that relatively small losses are dominantly determined by an intense gas flow with initial temperature of $38{ }^{\circ} \mathrm{C}$ in the inner channel; therefore, temperature difference $\Delta T$ between the biomass digester and the gas in the inner channel is small, implying that heat flux density is also very small. During the winter a dominant process is condensation in the overground part of the outer channel, while in the summer the determinative is condensation in the underground parts of both channels, where the temperature drops to $5-7^{\circ} \mathrm{C}$ (see distributions along the channels in the next chapter). Certainly, the total condensation rate under summer conditions is several times less than in winter conditions (see Fig. 3).

Comparison of latent heat power from condensation process (Fig. 6) and power of heat losses from the biogas digester (Fig. 7) shows that the latter is several times smaller. At the same time, the condensation-related heat power is comparable to the heat power transferred by the gas and water vapour mixture flowing from the bioreactor with initial temperature of $38^{\circ} \mathrm{C}$. This result confirms that condensation has a very significant effect on the heat exchange in the investigated dual layer shell type recuperation system, and the condensation process should be taken into account. 


\subsection{Distribution along Channels: Condensation Rate and Temperature}

Visualisation of condensation process and temperature distribution along both (inner and outer) channels is shown in Figs. 8-11. By analysing these images, it should be noted that

- vertical dashed lines show the boundaries between channel parts (digester roof, wall to the air/ground), where boundary conditions may change causing rapid changes in physical fields, e.g. different ground and air temperatures for an outer channel;

- line representing an inner channel starts at distance of $0 \mathrm{~m}$ and ends at 11 $\mathrm{m}$; for an outer channel the line is oriented in the opposite direction - it starts at distance of $11 \mathrm{~m}$ and ends at $0 \mathrm{~m}$;

- in the channel parts, where temperature increases (e.g., for the outer channel in the summer), condensation may also be negative, implying that the evaporation process takes place at these locations.

It is seen from the temperature distribution lines in Fig. 8, that after an increase of thermal insulation between the channels, a temperature decrease in the inner channel significantly reduces, while it grows in the outer channel. It is determined by less heat loss from the inner channel through its outer surface, causing less energy received by the outer channel inner surface, which leads to a rapid temperature drop in it. In case of an intensive gas flow, the influence of thermal insulation on temperature differences in channels becomes insignificant (compare both temperature lines in Fig. 9).
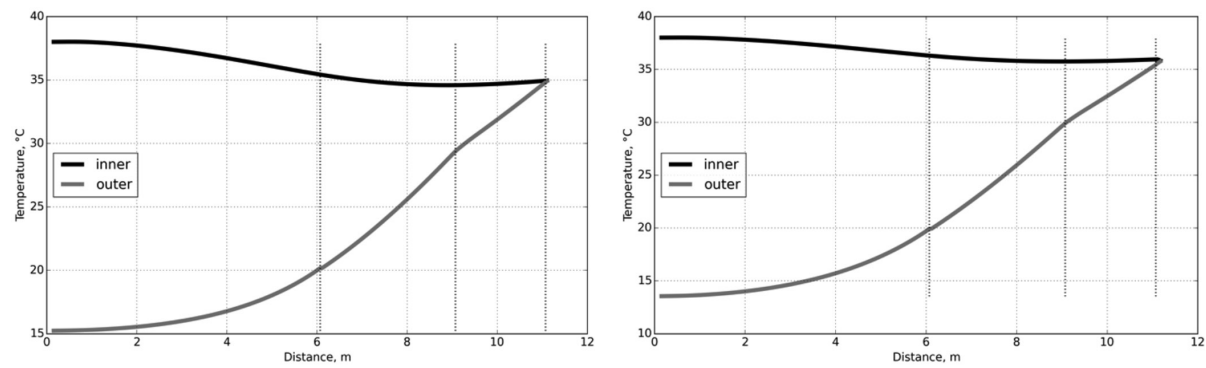

Fig. 8. Temperature $\left({ }^{\circ} \mathrm{C}\right.$ ) distributions for $75 \mathrm{~m}^{3} \mathrm{~h}^{-1}$ flow in the winter (air temperature of $0{ }^{\circ} \mathrm{C}$, ground temperature of $5^{\circ} \mathrm{C}$ ) in case of $1 \mathrm{~cm}$ (left) and $10 \mathrm{~cm}$ (right) thermal insulation between channels.
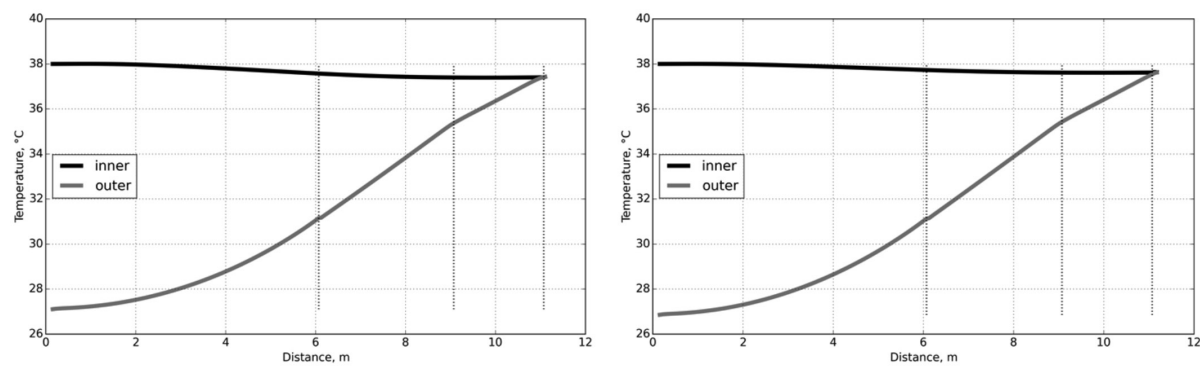

Fig. 9. Temperature $\left({ }^{\circ} \mathrm{C}\right.$ ) distributions for $200 \mathrm{~m}^{3} \mathrm{~h}^{-1}$ flow in the winter (air temperature of $0{ }^{\circ} \mathrm{C}$, ground temperature of $5^{\circ} \mathrm{C}$ ) in case of $1 \mathrm{~cm}$ (left) and $10 \mathrm{~cm}$ (right) thermal insulation between channels. 
Comparing a condensation rate in summer and winter conditions (Figs. 10, 11 ), it is seen that in case of low outside air temperature the condensation in the overground part of outer channel is dominant. In turn, hot air temperature and ground temperature of only $7{ }^{\circ} \mathrm{C}$ in the summer determine intensive condensation in the underground parts of the channel. As it is expected, the total amount of condensate during the summer is several times less than in the winter. The highest gas flow also means the largest total condensate amount (compare absolute values in Figs. 10 and $11)$.
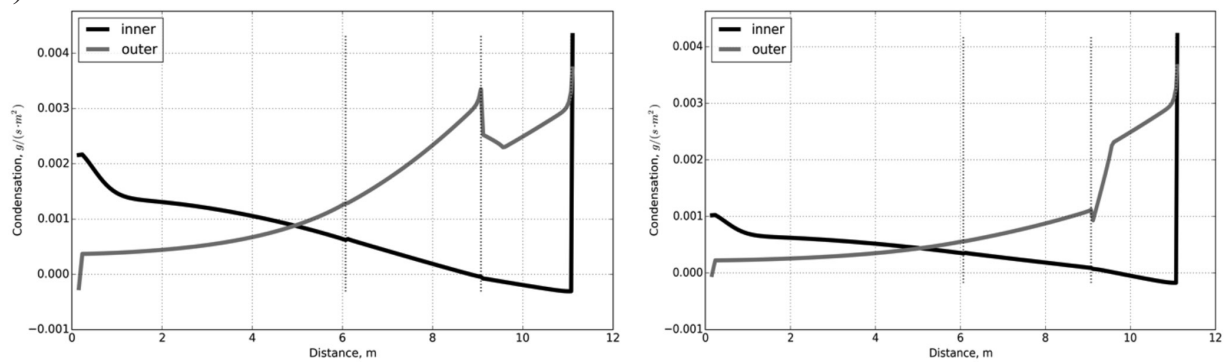

Fig. 10. Condensation rate $\left(\mathrm{g} \mathrm{s}^{-1} \mathrm{~m}^{-2}\right)$ distributions for $75 \mathrm{~m}^{3} / \mathrm{h}$ flow in channels with $1 \mathrm{~cm}$ thermal insulation in the winter at air temperature of $0{ }^{\circ} \mathrm{C}$, ground temperature of $5{ }^{\circ} \mathrm{C}$ (left) and in the summer at air temperature of $20^{\circ} \mathrm{C}$, ground temperature of $7^{\circ} \mathrm{C}$ (right).
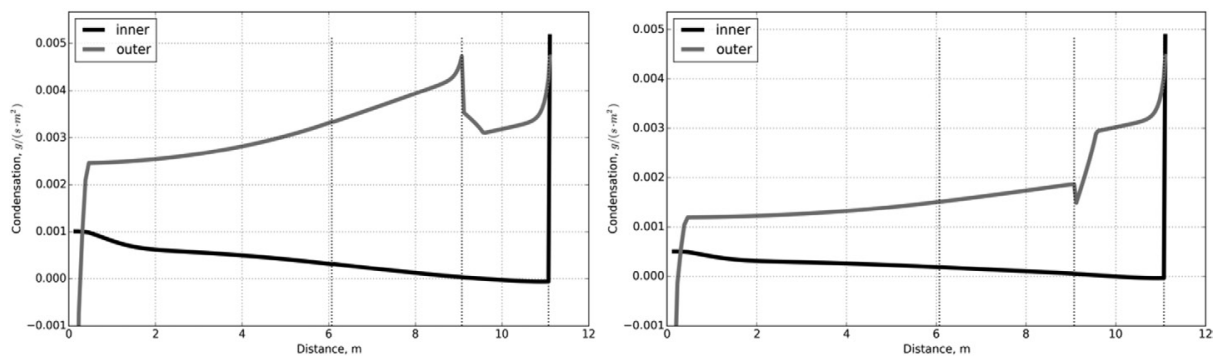

Fig. 11. Condensation rate $\left(\mathrm{g} \mathrm{s}^{-1} \mathrm{~m}^{-2}\right)$ distributions for $200 \mathrm{~m}^{3} \mathrm{~h}^{-1}$ flow in channels with $1 \mathrm{~cm}$ thermal insulation in the winter at air temperature of $0{ }^{\circ} \mathrm{C}$, ground temperature of $5^{\circ} \mathrm{C}$ (left) and in the summer at air temperature of $20^{\circ} \mathrm{C}$, ground temperature of $7{ }^{\circ} \mathrm{C}$ (right).

\section{CONCLUSIONS}

The developed 1D mathematical model allows extremely quickly and accurately calculating the temperature and latent heat distribution, as well as the total amount of condensate for gas and water vapour flow in a dual layer shell type recuperation system with different environmental and flow parameters. The parameter studies performed for different boundary conditions show the usability of this model for the optimisation of this type of cooling system, allowing for a detailed analysis of biogas dehumidification process.

Modelling results show that the latent heat of water vapour condensation plays an important role in the heat exchange process in the analysed system, so its in- 
clusion in the physical and mathematical model is essential to obtain an accurate amount of condensation and evaluate the heat losses from the digester for different conditions. Condensation rate results have been evaluated comparing them with a simplified condensation amount calculation.

Thermal insulation between counter-flow channels practically does not affect the amount of condensate, but its impact on total heat losses from the biogas digester is significant; therefore, usefulness of the insulation should be assessed taking into account other aspects, e.g. gas temperature and outlet temperature.

In general, the chosen dehumidifier solution with two channels on the digester roof and wall ensures both significant humid biogas drying and the reduction of heat loss from the reactor even without creation of an additional heat insulation layer.

\title{
ACKNOWLEDGEMENTS
}

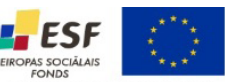

The current research has been supported by the Cohesion Fund (project No. L-KC-11-0005).

\section{REFERENCES}

1. Scott, S., \& Turra, F. (2015). Six Reasons to Dry Biogas to a Low Dewpoint before Combustion in a CHP Engine. Retrieved 10 June 2015, from http://www.parker.com/ literature/United Kingdom/PAR6841_Whitepaper_v3.pdf

2. Prassl, H. (2015). Biogas Purification and Assessment of the Natural Gas Grid in Southern and Eastern Europe. Retrieved 17 June 2015, from http://www.big-east.eu/bigeast_ reports/WP 2_Task 2.5-Report.pdf

3. Bergman, T., \& Incropera, F. (2011). Fundamentals of Heat and Mass Transfer (7th ed.). Hoboken, NJ: Wiley.

4. Langtangen, H. (2014). A Primer on Scientific Programming with Python. Berlin, Heidelberg: Springer Berlin Heidelberg.

5. Rasi, S., Veijanen, A., \& Rintala, J. (2007). Trace compounds of biogas from different biogas production plants. Energy, 32(8), 1375-1380. doi:10.1016/j.energy.2006.10.018

6. Harriman, L. (1990). The Dehumidification Handbook. Amesbury, MA: Munters Cargocaire.

\section{APVALKA TIPA DIVKAMERU REKUPERĀCIJAS SISTĒMAS UN BIOGĀZES SAUSINĀTĀJA MATEMĀTISKĀ MODELĒĚSANA}

\author{
S. Gendelis, A. Timuhins, A. Laizāns, L. Bandeniece
}

Kopsavi $1 \mathrm{kums}$

Pētījuma pamatmērķis ir izveidot bioreaktora divkameru apvalka tipa pretplūsmu rekuperācijas sistēmas matemātisko modeli. Šāda sistēma l̦auj samazināt siltuma zudumus no reaktora, ka arī samazināt ūdens daudzumu biogāzē bez papildu 
mehāniskām vai ķīmiskām komponentēm. Pamatideja ir izmantot bioreaktora sienas (apvalku) kā rekuperatoru, sienas ir veidotas no diviem slāņiem (kamerām), kurās pretējos virzienos plūst biogāze. Pētījuma rezultātā tika izstrādāts siltuma un tvaika plūsmas matemātiskais modelis un tika veikti aprēķini plašā parametru diapazonā. Modelis ir reducēts līdz 1D gadījumam, lai būtiski paātrinātu skaitliskus aprēķinus. Tiek parādīts, ka kondensācijas siltums ir svarīga bioreaktora siltuma bilances komponente un kondensācijas sadalījums galvenokārt ir atkarīgs no izolācijas slāṇa starp kamerām un āra temperatūras. Modelēšanas rezultāti l̦auj izvelēties optimālus geometriskos parametrus un materiālu îpašības noteiktiem gāzes plūsmas ātrumiem un ārējiem apstākḷiem.

17.08.2015. 